\title{
Optimal economic dispatch using particle swarm optimization in Sulselrabar system
}

\author{
Marhatang1, Muhammad Ruswandi Djalal $^{2}$ \\ ${ }^{1}$ Energy Conversion Study Program, Department of Mechanical Engineering, State Polytechnic of Ujung Pandang, Makassar, Indonesia \\ ${ }^{2}$ Energy Power Plant Study Program, Department of Mechanical Engineering, State Polytechnic of Ujung Pandang, Makassar, Indonesia
}

\begin{tabular}{l} 
Article Info \\
\hline Article history: \\
Received Apr 4, 2021 \\
Revised Nov 4, 2021 \\
Accepted Nov 20, 2021 \\
\hline
\end{tabular}

Keywords:

Ant colony optimization

Economic dispatch

Lagrange

Losses

Particle swarm optimization

\begin{abstract}
In this study, a particle swarm optimization (PSO) is proposed to optimize the cost of generating thermal plants in the South Sulawesi system. The study was con ducted by analyzing several methods using the lagrange and ant colony optimization (ACO). PSO algorithm converges on the $11^{\text {th }}$ iteration algorithm with the lowest generation cost obtained, which is Rp129687962.17/hour. While the ACO algorithm converges on the $34^{\text {th }}$ iteration with a generation cost of Rp131,473,269.39/hour. The results of optimization using PSO produce a total thermal power of $400.75 \mathrm{MW}$ and losses of $26.15 \mathrm{MW}$. The PSO method is able to reduce the cost of generating the South Sulawesi system by Rp11,118,312.07/hour or 7.9\%. While using the ACO method generates a generation cost of Rp131,473,269.39/hour to generate power of 400,812 MW with losses of 26,219 MW. The ACO method is able to reduce the cost of generating the South Sulawesi system by Rp9,333,004.9/hour or 6.62\%. PSO algorithm provides the lowest cost calculation of generator compared with conventional methods and ACO smart methods. This is also shown in the calculation process, the PSO method completes calculations faster than the ACO method.
\end{abstract}

This is an open access article under the CC BY-SA license.

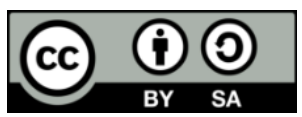

\section{Corresponding Author:}

Marhatang

Energy Conversion Study Program, Department of Mechanical Engineering, State Polytechnic of Ujung Pandang

J1. Perintis Kemerdekaan KM. 10, Makassar 90245, Indonesia

Email: marhatang@poliupg.ac.id

\section{INTRODUCTION}

In a power plant center, good management is needed in regulating the loading and the amount of power that must be sent by the generator into the system. Operational management at the power plant is very important, especially in thermal plants that operate with fuel to drive turbines. Changes in the load on the electric power system will encourage additional fuel consumption per unit time in thermal power plants to produce electricity, this is commonly referred to as the input-output characteristics of the generator. The increasingly expensive fuel costs in thermal generators need to be optimized for use, so that minimum costs are obtained [1].

The Sulselrabar system operates at $150 \mathrm{kV}$ and consists of 46 transmission lines. This system connects load centers in Sulselrabar such as the capital city of Makassar, Pare-Pare and several districts such as Maros, Pangkep, and others. The Sulselrabar system has 37 buses and consists of several thermal and nonthermal generators. For thermal generators there are 12 generating units and 4 hydro or non-thermal generating units. The Sulselrabar system is a large system so a comprehensive study is needed so that it can support the system's performancev [2]. 
In this research, a study on the South Sulawesi electricity system will be proposed, namely economic dispatch. In previous studies, previous economic dispatch studies have been conducted. Some of these studies produce a combination of economic loading for generating units in the South Sulawesi system. But the development of the system and also the emergence of several new optimization methods, we need a further study of economic dispatch.

Particle swarm optimization (PSO) method is an undeterministic method or smart method. PSO is an evolutionary computational technique, in which the population in the PSO is based on an algorithm search and begins with a random population called a particle. The application of PSO as an economic dispatch optimization method has been investigated by [3]-[7]. The study discusses the implementation of the PSO algorithm to solve economic dispatch problems. Previous research on economic dispatch in the South Sulawesi system has been conducted. In research [8] discusses economic dispatch using the PSO method. From the results of the study the generator data used did not cover all of the generators in the system, especially thermal plants. The Sulselrabar system has now developed with the addition of several thermal plants. In research [9], the implementation of the ant colony algorithm is explained as an optimization method. From the results of this study obtained the old ant colony computing process. In addition, the optimization results obtained are not so significant with the calculation process using the conventional lagrange method. In [4], [6] discusses the implementation of the PSO in calculating the cost of generation in a multi-engine system, and shows optimal results in tuning. In research [5] discusses the optimization of generation costs in small systems with a case study of a 9 bus system and 3 generators. Research on small scale systems has also been carried out by [10], who discusses the implementation of economic dispatch in microgrid systems.

This research will propose a new approach for optimization of generation costs in large multinational systems, especially in the South Sulawesi system. In this study, we consider transmission losses and the equality and inequality limits of the generator [3]. The final result of this research is the optimization of optimal power generation so that the cheapest generation costs are obtained.

\section{RESEARCH METHOD}

Optimal operation of the generator must pay attention to equality constraints and inequality constraints. Equality constraint is the power limit generated by each generator which is equal to the total load requirement and transmission losses, expressed by the following (1) [11]. Loss coefficients can be considered constant for changes in the output power of each generator in the system.

$$
\sum_{i=1}^{N} P_{i}=P_{R}+P_{L}
$$

Where:

$\mathrm{Pi} \quad=$ Generator output power $(\mathrm{MW})$

PR = Total load (MW)

PL = Transmission losses (MW)

while the inequality constraint is the output power produced by the generator that must be greater than or equal to the minimum permitted power and less than or equal to the maximum permitted power [12]

$$
\begin{aligned}
& P_{i \min } \leq P_{i} \leq P_{i \max } \\
& P_{L}=\sum_{i=1}^{N} \sum_{j=1}^{N} P_{i} B_{i j} P_{j}+\sum_{i=1}^{N} B_{i 0} P_{j}+B_{00}
\end{aligned}
$$

where:

$\mathrm{P}_{\mathrm{L}}$ : Losses.

$B_{\mathrm{ij}}$ : Losses coefficients.

$\mathrm{P}_{\mathrm{i}}, \mathrm{P}_{\mathrm{i}}$ : Generator output

$\mathrm{B}_{\mathrm{i} 0}, \mathrm{~B}_{00}$ : Losses constant

\subsection{Particle swarm optimization}

Particle swarm optimization (PSO) is an artificial intelligence method that was discovered in 1995 [13], [14]. This algorithm works by adopting the movement behavior of a flock of birds or fish in search of food so that it can be applied to scientific and engineering research methods. The main advantages of the 
PSO algorithm are simple algorithm structure, easy to use, easy to set parameters, and very good efficiency [10], [15]. The weight improvement function is determined by the following (4).

$$
w(t)=\left(w_{\max }-w_{\min }\right) x \frac{\text { iterasi }_{\max }-i \operatorname{terasi}(t)}{\text { iterasi }_{\max }}+w_{\min }
$$

Where:

$$
\begin{array}{ll}
\mathrm{W}(\mathrm{t}) & : \text { Weight } \\
\mathrm{W}_{\max } & : \text { Maximum weight value } \\
\mathrm{W}_{\min } & : \text { Minimum weight value } \\
\text { Iter }_{\max } & : \text { Maximum Iteration } \\
\text { Iter(t) } & : \text { Iteration }
\end{array}
$$

Inertia weight values are usually set between 0.4 and 0.9 . The concept of inertia weight was developed by Shi and Eberhart in 1998 which inspired the modification of particle velocity and position using the adjustable inertia weight parameter. Velocity and particle position equation [16], [17]:

$$
V_{i j}^{t}=\omega x V_{i j}^{t-1}+c_{1} x r_{1} x\left(P_{\text {best }_{i j}}^{t-1}-X_{i j}^{t-1}\right)+c_{2} x r_{2} x\left(G_{\text {best }_{i}}^{t-i}-X_{i j}^{t-1}\right)
$$

For $I=1,2, \ldots, \mathrm{N}_{\mathrm{D}} ; j=1, \ldots, \mathrm{N}_{\mathrm{par}}$.

Where:

$\mathrm{t} \quad$ : Calculate iteration

$V_{i j}^{t} \quad:$ The ij dimension of the particle velocity at iteration t.

$X_{i j}^{t} \quad:$ The ij dimension of the particle position in the iteration $\mathrm{t}$.

$\omega \quad$ : Weight of inertia

$\mathrm{c}_{1}, \mathrm{c}_{2} \quad$ : Positive acceleration coefficient

$P_{\text {best }}{ }_{i j}$ : : The ij dimension from the best position is reached until iteration $t-1$

$G_{\text {best }}{ }_{i j}^{t-1}$ : Dimension I of all best positions is achieved until t-1 iteration

$N_{D} \quad$ : Number of decision variables

$N_{\text {par }} \quad$ : Number of swarm

$\mathrm{r}_{1}, \mathrm{r}_{2} \quad$ : Random numbers are evenly distributed in the range $[0,1]$; the latest value is generated at any time.

PSO was developed based on the following model [18]:

a. When a bird approaches a food source, it will quickly send information to other birds.

b. After receiving the information, the other birds follow in groups.

PSO parameters used include [19]:

- $\quad$ Number of swarms $=30$

- $\quad$ Number of variables $=16$

- $\quad$ Maximum iteration $=50$

- Social constant $=0.5$

- Cognitive constant $=0.01$

- Inertia $(\mathrm{w})=0.01$

While the ant colony optimization (ACO) parameters include [20], [21]:

- Number of ants $=10$

- $\quad$ Max Iteration=100

- $\quad$ Alpha $=0.9$

Research begins by collecting system data. Then make a modeling of the Sulselrabar system to be integrated with the PSO algorithm. Then make PSO modeling in MATLAB software. Figure 1 shows the flowchart of the research conducted.

\section{RESULTS AND ANALYSIS}

In this study, the completion of economic dispatch uses several methods including the conventional Lagrange method, the ant colony optimization (ACO) method, and the proposed method, namely particle swarm optimization (PSO). The case study used is the Sulselrabar system. The algorithm performs computations to calculate the cheapest combination of thermal generation. In this study, 4 non-thermal power plants were maximized. The PSO algorithm works with the lowest cost generation objective function. The 
solution begins by calculating the input-output characteristics of the generator with the following (6) [22], [23].

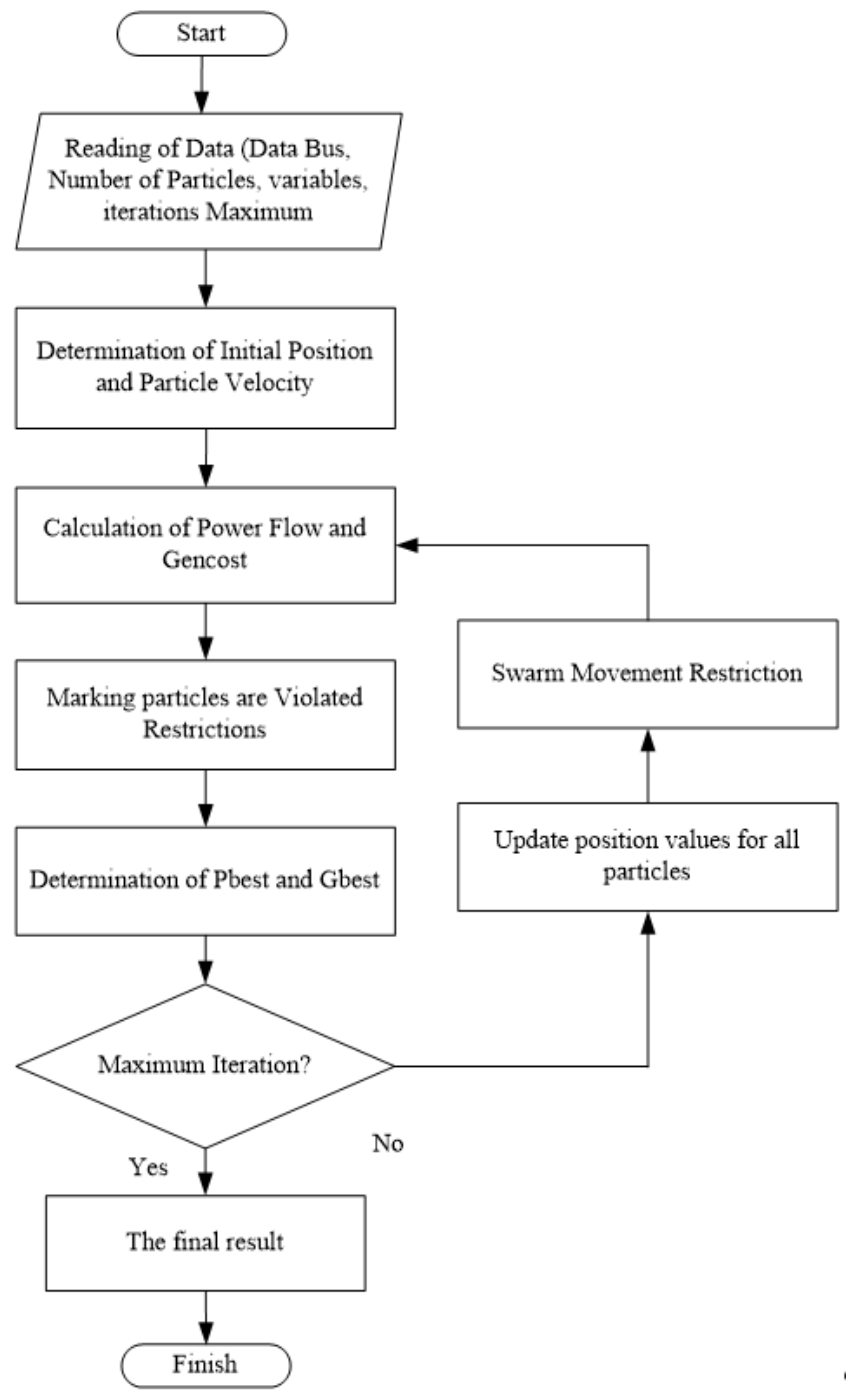

Figure 1. Particle swarm optimization flowchart

$$
C_{t}=\sum_{i=1}^{n_{g}} \alpha_{i}+\beta_{i} P_{i}+\gamma_{i} P_{i}^{2}
$$

To obtain stable generator performance, the operation of the generator should not exceed or be less than the generator capacity [24]. Therefore, the generator power production must be limited by the equality constraint as shown in (7). In addition, it must also pay attention to the limits of the inequality constraint as shown in (8) [25].

$$
\begin{aligned}
& \sum_{i=1}^{n_{g}} P_{i}=P_{D} \\
& P_{i_{\text {min }}} \leq P_{i} \leq P_{i_{\text {max }}}
\end{aligned}
$$




\subsection{Thermal generator input-output and fuel cost characteristics}

The computational process begins by calculating the input-output characteristics of the thermal generator [26]. Then determine the fuel cost equation by multiplying the input-output equation by the price of the fuel used. The results of the calculation of the input output characteristics and cost functions are shown in Table 1 [9].

Table 1. IO characteristics and cost function

\begin{tabular}{clcc}
\hline No & \multicolumn{1}{c}{ Unit } & Input-Output Equation (Liter/Jam) & Input-Output Equation (Liter/Jam) \\
\hline 1 & PLTD Pare-Pare & $714.0000+567.4000 \mathrm{P}-3.2941 \mathrm{P}^{2}$ & $6211800+4936380 \mathrm{P}-28658.67 \mathrm{P}^{2}$ \\
2 & PLTD Suppa & $2070+178.6 \mathrm{P}+0.4 \mathrm{P}^{2}$ & $18009000+1553820 \mathrm{P}+3480 \mathrm{P}^{2}$ \\
3 & PLTU Barru & $2805.6+251.6 \mathrm{P}-0.11976 \mathrm{P}^{2}$ & $17675280+1585080 \mathrm{P}+754.488 \mathrm{P}^{2}$ \\
4 & PLTU Tello & $558+174.5 \mathrm{P}+1.375 \mathrm{P}^{2}$ & $3515400+1099350 \mathrm{P}+8662.5 \mathrm{P}^{2}$ \\
5 & PLTD Agrekko/T.Lama & $771.975+160 \mathrm{P}+2.7397 \mathrm{P}^{2}$ & $6716182.5+1392000 \mathrm{P}+23835.39 \mathrm{P}^{2}$ \\
6 & PLTD Sgmnsa & $617.625+477.25 \mathrm{P}-4.1667 \mathrm{P}^{2}$ & $5373337.5+4152075 \mathrm{P}-36250.29 \mathrm{P}^{2}$ \\
7 & PLTD Arena/Jeneponto & $629.475+176.3 \mathrm{P}+4.8052 \mathrm{P}^{2}$ & $5476432.5+1533810 \mathrm{P}+41805.24 \mathrm{P}^{2}$ \\
8 & PLTD Matekko/Bulukumba & $506.25+124.9 \mathrm{P}+9.4444 \mathrm{P}^{2}$ & $4404375+1086630 \mathrm{P}+82166.28 \mathrm{P}^{2}$ \\
9 & PLTD Pajelasang/Soppeng & $432+66.2 \mathrm{P}+12.5 \mathrm{P}^{2}$ & $3758400+575940 \mathrm{P}+108750 \mathrm{P}^{2}$ \\
10 & PLTGU Sengkang & $4418.89+38.0952 \mathrm{P}+0.021898 \mathrm{P}^{2}$ & $27839000.000+240000.00 \mathrm{P}+137.9539 \mathrm{P}^{2}$ \\
11 & PLTD Malea/Makale & $165.75+409.5 \mathrm{P}+5.7692 \mathrm{P}^{2}$ & $1442025+3562650 \mathrm{P}+50192.04 \mathrm{P}^{2}$ \\
12 & PLTD Palopo & $103.5+112.4 \mathrm{P}+50 \mathrm{P}^{2}$ & $900450+977880 \mathrm{P}+435000 \mathrm{P}^{2}$ \\
\hline
\end{tabular}

\subsection{Analysis and discussion}

The case study used is based on previous research, in which the settlement method uses an intelligent ant colony optimization (ACO) algorithm and the conventional Lagrange. Table 2 shows the real generation power and costs for the thermal unit of the South Sulawesi system at peak evening load before optimization and the comparison of the results of simulations carried out using the proposed method namely particle swarm optimization (PSO) algorithm, then compared with the ACO algorithm, and the Lagrange. The graph of convergence optimization of generation costs using PSO is shown in Figure 2.

Table 2. The complete optimization results

\begin{tabular}{|c|c|c|c|c|c|c|c|c|}
\hline \multirow[t]{2}{*}{ Unit } & \multicolumn{2}{|r|}{ Real } & \multicolumn{2}{|c|}{ Lagrange } & \multicolumn{2}{|c|}{ Ant Colony } & \multicolumn{2}{|c|}{ PSO } \\
\hline & $\mathrm{P}(\mathrm{MW})$ & Cost (Rp/hr) & $\mathrm{P}(\mathrm{MW})$ & Cost (Rp/hr) & $\mathrm{P}(\mathrm{MW})$ & Cost (Rp/hr) & $\mathrm{P}(\mathrm{MW})$ & Cost (Rp/hr) \\
\hline 1 & 20.1 & 9385464.873 & 19.40 & 9119159.49 & 18.50 & 8772640.01 & 10.50 & 5488737.86 \\
\hline 2 & 62.2 & 12812016.72 & 31.98 & 7125923.05 & 60.03 & 12382534.57 & 59.73 & 12323912.16 \\
\hline 3 & 44.7 & 10360370.52 & 44.00 & 10202568.76 & 41.40 & 9622921.45 & 33.55 & 7935567.73 \\
\hline 4 & 29.7 & 4380719.96 & 19.80 & 2867857.65 & 17.80 & 2582845.65 & 28.38 & 4169183.92 \\
\hline 5 & 19.3 & 4246022.69 & 19.00 & 4176875.82 & 21.88 & 4858396.36 & 18.39 & 4036545.83 \\
\hline 6 & 12.3 & 5095955.36 & 27.60 & 9235658.65 & 29.20 & 9570548.02 & 19.08 & 7140357.97 \\
\hline 7 & 19.6 & 5159900.95 & 23.86 & 6587284.55 & 13.36 & 3342993.46 & 18.66 & 4864960.35 \\
\hline 8 & 9.0 & 2083951.36 & 6.30 & 1451132.36 & 11.94 & 2909265.78 & 9.35 & 2175760.65 \\
\hline 9 & 15.1 & 3725118.15 & 14.56 & 3519839.04 & 11.52 & 2482548.48 & 11.24 & 2395951.36 \\
\hline 10 & 192.9 & 79268321.18 & 184.38 & 76780078.63 & 166.10 & 71509642.44 & 188.35 & 77937456.65 \\
\hline 11 & 3.5 & 1452615.24 & 3.730 & 1542902.63 & 3.520 & 1460445.24 & 2.02 & 885723.75 \\
\hline 12 & 6.9 & 2835817.20 & 6.060 & 2280116.88 & 5.560 & 1978487.88 & 1.50 & 333803.93 \\
\hline Total & 435.3 & 140806274.24 & 400.67 & 134889397.56 & 400.81 & 131473269.39 & 400.75 & 129687962.17 \\
\hline
\end{tabular}

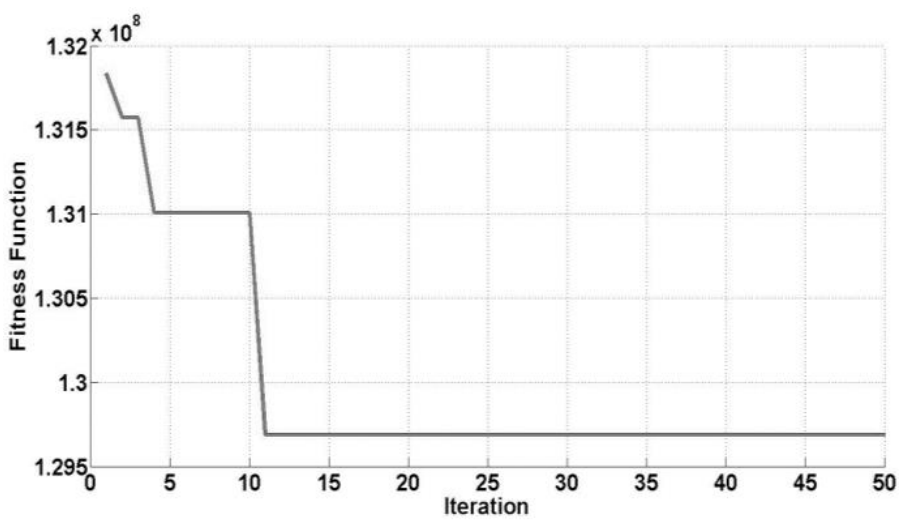

Figure 2. Graph of convergence optimization using particle swarm optimization 
Table 2 is a preliminary study of the calculation of generator costs before being optimized in a case study of peak evening loads, the generation load charged to the thermal unit of $435.3 \mathrm{MW}$, with a total generation cost of Rp140,806,274.24. Losses generated before optimization were 26,299 MW. The total system load is 532.3 MW. 4 Hydro power plant units bear respectively: Bakaru $126 \mathrm{MW}$, Pinrang $0.3 \mathrm{MW}$, Sinjai 3.5 MW, Bili-Bili 7.1 MW. Furthermore, by using the proposed method that is using a smart method based on PSO algorithm, the generation results are more optimal than the smart method based on ACO algorithm. As another comparison method in this research also used the conventional Lagrange. The complete optimization results are shown in Table 2.

\subsection{Analysis}

In the condition before optimization, the total cost of generation is Rp140,806,274.24/hour with a power of 435.3 MW and losses of 26,299 MW. The first optimization is done using conventional lagrange and generates a generation cost of Rp134,889,397.56/hour with a power of 400.67 MW and losses of 28.352 MW. From the results of these calculations, the cost of generation can be reduced to Rp5,916,876.7/hour or $4.2 \%$ at night peak load. The most expensive generation costs are obtained from the Sengkang Pembangkit Listrik Tenaga Gas (PLTGU) unit, which in the system functions as a slack bus, which is Rp76,780,078,632/hour, with a power of 184,380 MW. While the cheapest generation costs are obtained from the Matekko Pembangkit Listrik Tenaga Diesel (PLTD) unit, which is Rp1,451,132,365/hour, with a power of $6.3 \mathrm{MW}$.

Next, use the ant colony optimization (ACO) method. From the calculation results [9], CO converges on the $34^{\text {th }}$ iteration with a generation cost of Rp131,473,269.39/hour. From the computational results, ACO generates a generation cost of Rp131,473,269.39/hour with a power of 400,812 MW with losses of 26,219 MW. From these results, ACO was able to reduce the generation cost of Rp9.333.004.9/hour or $6.62 \%$. The most expensive generating unit of the Sengkang Pembangkit Listrik Tenaga Gas (PLTGU) produces the most expensive thermal generation cost of Rp71,509,642,449/hour, with a power of 166,102 MW. While the cheapest thermal generating unit at the Pembangkit Listrik Tenaga Diesel (PLTD) Malea Makale plant is Rp1,460,445,245/hour, with a power of 3,520 MW.

Figure 2 is a graph of the convergence of calculations using PSO. The calculation process is carried out for 50 iterations, and in the $11^{\text {th }}$ iteration the PSO algorithm has found the cheapest generation cost, which is Rp129,687,962.17/hour with a power of 400.75 MW and losses of 26.15 MW. From these results, PSO was able to reduce the generation cost of Rp11,118,312.07/hour or 7.9\%. The Sengkang PLTGU generating unit produces the most expensive thermal generation costs, namely Rp77,937,456.65/hour, with a power of $188.35 \mathrm{MW}$. While the cheapest thermal generating unit at the Palopo PLTD plant is Rp333.803.93/hour, with a power of 1.5 MW.

From the results of the analysis, the PSO algorithm gives the cheapest generation cost calculation results compared to the conventional method and the smart ACO method. This is also shown in the calculation process, the PSO method is faster in completing the calculation than the ACO method. Losses produced by the PSO method are smaller than other methods. Figure 3 shows a comparison of the generation costs at night peak load for each method.

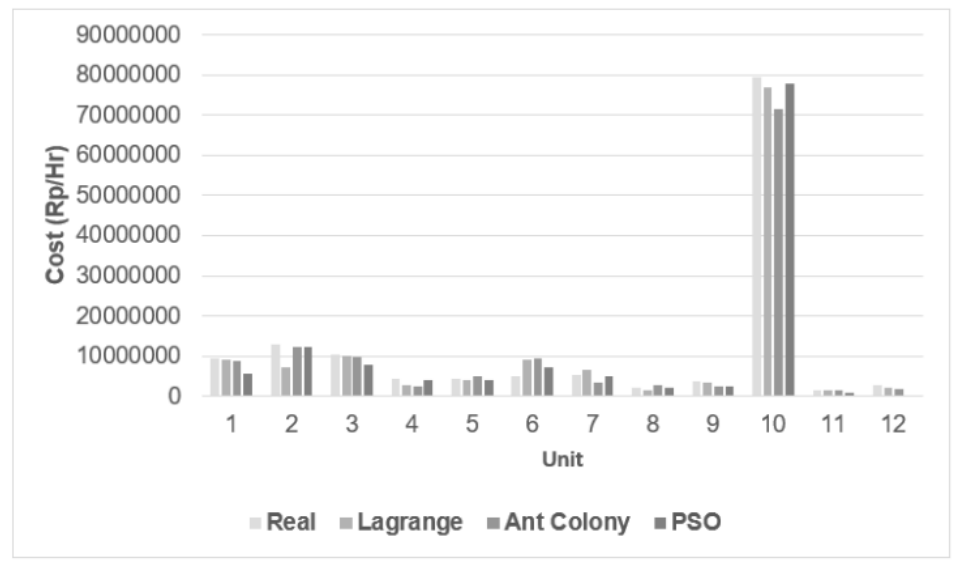

Figure 3. Comparison of the costs of generating peak evening loads 


\section{CONCLUSION}

From the analysis results, the particle swarm optimization (PSO) computation process algorithm converges on the $11^{\text {th }}$ iteration, where the PSO algorithm has found the cheapest generation cost of Rp129,687,962.17/hour. While the ant colony optimization (ACO) algorithm converges on the $34^{\text {th }}$ iteration with a generation cost of Rp131,473,269.39/hour. From the results of the analysis using the conventional lagrange of generation costs Rp134,889,397.56/hour with active power 400.67 MW and losses of 28.352 MW. The ACO generates a total generation cost of Rp131,473,269.39/hour with active power of 400,812 MW and losses of 26,219 MW. Using the PSO method generates a total generation cost of Rp129,687,962.17/hour with active power 400.75 MW and losses of $26.15 \mathrm{MW}$. The lagrange is able to reduce the cost by Rp5,916,876.7/hour or $4.2 \%$. Ant Colony is able to reduce the cost by Rp9,333,004.9/hour or $6.62 \%$. PSO is able to reduce the cost by Rp11,118,312.07/hour or $7.9 \%$.

\section{ACKNOWLEDGEMENTS}

This work was supported by State Polytechnic of Ujung Pandang.

\section{REFERENCES}

[1] M. R. Djalal, A. Imran, and I. Robandi, "Optimal placement and tuning power system stabilizer using participation factor and imperialist competitive algorithm in $150 \mathrm{kV}$ South of Sulawesi system," in 2015 International Seminar on Intelligent Technology and Its Applications (ISITIA), May 2015, pp. 147-152, doi: 10.1109/ISITIA.2015.7219970.

[2] M. Y. Yunus, M. R. Djalal, and M. Marhatang, "Optimal design power system stabilizer using firefly algorithm in interconnected 150 kV Sulselrabar System, Indonesia," International Review of Electrical Engineering (IREE), vol. 12, no. 3, Jun. 2017, doi: 10.15866/iree.v12i3.11136.

[3] A. Mahor, V. Prasad, and S. Rangnekar, "Economic dispatch using particle swarm optimization: a review," Renewable and Sustainable Energy Reviews, vol. 13, no. 8, pp. 2134-2141, Oct. 2009, doi: 10.1016/j.rser.2009.03.007.

[4] H. M. Z. Iqbal, A. Ashraf, and A. Ahmad, "Power economic dispatch using particle swarm optimization," Jun. 2015, doi: 10.1109/PGSRET.2015.7312202.

[5] M. Murtadha Othman, M. Affendi Ismail Salim, I. Musirin, N. Ashida Salim, and M. Lutfi Othman, "Dynamic economic dispatch assessment using particle swarm optimization technique," Bulletin of Electrical Engineering and Informatics, vol. 7, no. 3, pp. 458-464, Sep. 2018, doi: 10.11591/eei.v7i3.1278.

[6] M. N. Alam, "State-of-the-art economic load dispatch of power systems using particle swarm optimization," Dec. 2018. ArXiv:1812.11610.

[7] V. K. Jadoun, N. Gupta, K. R. Niazi, and A. Swarnkar, "Nonconvex economic dispatch using particle swarm optimization with time varying operators," Advances in Electrical Engineering, vol. 2014, pp. 1-13, Oct. 2014, doi: 10.1155/2014/301615.

[8] S. Humena, S. Manjang, and I. C. Gunadin, "Optimization economic power generation using modified improved PSO algorithm methods," Journal of Theoretical and Applied Information Technology, vol. 93, no. 2, pp. 522-530, 2016.

[9] Tasrif, Suyono, Hadi, and R. Nur, "Economic dispatch in $150 \mathrm{KV}$ sulselrabar electrical system using ant colony optimization," IOSR Journal of Electrical and Electronics Engineering (IOSR-JEEE), vol. 13, no. 3, pp. 28-35, 2018, doi: 10.9790/16761303022835.

[10] D. McLarty, N. Panossian, F. Jabbari, and A. Traverso, "Dynamic economic dispatch using complementary quadratic programming," Energy, vol. 166, pp. 755-764, Jan. 2019, doi: 10.1016/j.energy.2018.10.087.

[11] G. Xiong et al., "A novel method for economic dispatch with across neighborhood search: a case study in a provincial power grid, China," Complexity, vol. 2018, pp. 1-18, Nov. 2018, doi: 10.1155/2018/2591341.

[12] Z. Younes, I. Alhamrouni, S. Mekhilef, and M. Reyasudin, "A memory-based gravitational search algorithm for solving economic dispatch problem in micro-grid," Ain Shams Engineering Journal, vol. 12, no. 2, pp. 1985-1994, Jun. 2021, doi: 10.1016/j.asej.2020.10.021.

[13] M. Imran, R. Hashim, and N. E. A. Khalid, "An overview of particle swarm optimization variants," Procedia Engineering, vol. 53, pp. 491-496, 2013, doi: 10.1016/j.proeng.2013.02.063.

[14] G. Pereira, "Particle swarm optimization," INESCID and Instituto Superior Tecnico, vol. 15, 2011.

[15] M. F. Aranza, J. Kustija, B. Trisno, and D. L. Hakim, "Tunning PID controller using particle swarm optimization algorithm on automatic voltage regulator system," IOP Conference Series: Materials Science and Engineering, vol. 128, no. 1, Apr. 2016, doi: 10.1088/1757-899X/128/1/012038.

[16] M. Saini, A. M. Shiddiq Yunus, and M. R. Djalal, "Optimal PSS design using particle swarm optimization under load shedding condition," in Proceedings - 2020 International Seminar on Intelligent Technology and Its Application: Humanification of Reliable Intelligent Systems, ISITIA 2020, Jul. 2020, pp. 405-410, doi: 10.1109/ISITIA49792.2020.9163779.

[17] Z. Qi, Q. Shi, and H. Zhang, "Tuning of digital PID controllers using particle swarm optimization algorithm for a CAN-based DC motor subject to stochastic delays," IEEE Transactions on Industrial Electronics, vol. 67, no. 7, pp. 5637-5646, Jul. 2020, doi: 10.1109/TIE.2019.2934030.

[18] H. M. Salman, A. K. M. Al-Qurabat, and A. A. Riyadh Finjan, "Bigradient neural network-based quantum particle swarm optimization for blind source separation," IAES International Journal of Artificial Intelligence (IJ-AI), vol. 10, no. 2, pp. 355-364, Jun. 2021, doi: 10.11591/ijai.v10.i2.pp355-364.

[19] M. I. Solihin, L. F. Tack, and M. L. Kean, "Tuning of PID controller using particle swarm optimization (PSO)," International Journal on Advanced Science, Engineering and Information Technology, vol. 1, no. 4, 2011, doi: 10.18517/ijaseit.1.4.93.

[20] Y. Dhieb, M. Yaich, A. Guermazi, and M. Ghariani, "PID controller tuning using ant colony optimization for induction motor," Journal of Electrical Systems, vol. 15, no. 1, pp. 133-141, 2019.

[21] I. Chiha, N. Liouane, and P. Borne, "Tuning PID controller using multiobjective ant colony optimization," Applied Computational Intelligence and Soft Computing, vol. 2012, pp. 1-7, 2012, doi: 10.1155/2012/536326.

[22] K. Ma, C. Wang, J. Yang, Q. Yang, and Y. Yuan, "Economic dispatch with demand response in smart grid: Bargaining model and solutions," Energies, vol. 10, no. 8, p. 1193, Aug. 2017, doi: 10.3390/en10081193. 
[23] J. Zhang, J. Zhang, F. Zhang, M. Chi, and L. Wan, "An improved symbiosis particle swarm optimization for solving economic load dispatch problem," Journal of Electrical and Computer Engineering, vol. 2021, pp. 1-11, Jan. 2021, doi: $10.1155 / 2021 / 8869477$.

[24] N. M. Azkiya, A. G. Abdullah, and H. Hasbullah, "Economic dispatch and operating cost optimization for thermal power in 500 KV system using genetic algorithm (GA)," IOP Conference Series: Materials Science and Engineering, vol. 434, no. 1, Dec. 2018, doi: 10.1088/1757-899X/434/1/012013.

[25] B. Huang, C. Zheng, Q. Sun, and R. Hu, "Optimal economic dispatch for integrated power and heating systems considering transmission losses," Energies, vol. 12, no. 13, Jun. 2019, doi: 10.3390/en12132502.

[26] B. Dey, B. Bhattacharyya, and F. P. G. Márquez, "A hybrid optimization-based approach to solve environment constrained economic dispatch problem on microgrid system," Journal of Cleaner Production, vol. 307, Jul. 2021, doi: 10.1016/j.jclepro.2021.127196.

\section{BIOGRAPHIES OF AUTHORS}

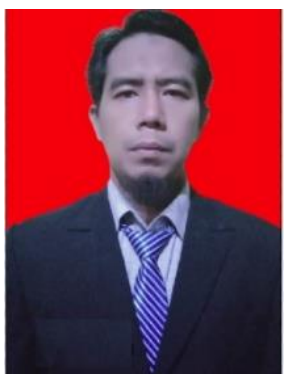

Marhatang (D) 8. SC P was born in Soppeng-Indonesia on November 17, 1974. He received bachelor degree from Electronic Engineering Polytechnic Institute of Surabaya (Surabaya, Indonesia), majors in Electrical Engineering in 2002. Then, master degree from Hasanuddin University (Makassar, Indonesia), majors in Electrical Engineering in 2012. His research about, Power Electronic, Renewable Energy, and Electrical Power System. Now, He is lecturer at State Polytechnic of Ujung Pandang (PNUP). He can be contacted at email: marhatang@ poliupg.ac.id.

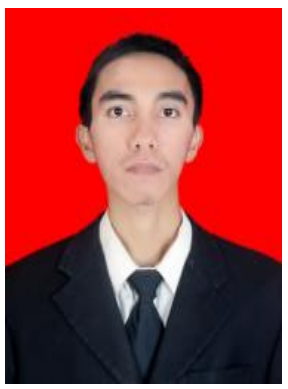

Muhammad Ruswandi Djalal (D) 8 SC $\mathrm{P}$ was born in Makassar-Indonesia on March 11, 1990. He received bachelor degree from State Polytechnic of Ujung Pandang (Makassar, Indonesia), majors in Energy Generation engineering in 2012. Then, master degree from Sepuluh Nopember Institute of Technology, (ITS Surabaya, Indonesia), majors in Power System Engineering in 2015. His research about, Power System Operation and Control, Renewable Energy and Artificial Intelligent. Now, He is lecturer at State Polytechnic of Ujung Pandang (PNUP). He can be contacted at email: wandi@poliupg.ac.id. 